\title{
The Impact of "Terroir" on Vegetative Equilibrium of Vines, in Relation with the Quality Potential of the Grape Harvest
}

\author{
Liliana PIRCALABU ${ }^{1 *)}$, Aurelia TUDORACHE ${ }^{1)}$, Adrian SERDINESCU ${ }^{1)}$ and Anca Dragunescu ${ }^{2)}$ \\ ${ }^{1}$ Research Institute for Viticulture and Enology Valea Calugareasca, Romania; street Valea Mantei, No. \\ 1, Valea Calugareasca, Zip code: 107620; \\ ${ }^{2}$ Banat University of Agricultural Sciences and Veterinary Medicine, Timisoara, Calea Aradului, No. 119, \\ zip code: 300645. \\ ${ }^{*}$ Corresponding author, e-mail: lilianapircalabu@yahoo.com
}

Bulletin UASVM Horticulture 72(1) / 2015

Print ISSN 1843-5254, Electronic ISSN 1843-5394

Doi:10.15835/buasvmcn-hort:10731

\begin{abstract}
In evaluating the quality of the viticultural terroir there are use different quality parameters. The exposed leaf area (SFE) currently considered an indicator better than planting density to be used as a quality factor in the AOC regulations. Getting a projected yield, in terms of quality and quantity, it can be achieved only by limiting the vegetative growth at a certain level to stimulate the fructification, but under the conditions of maintaining a photosynthetic activity to satisfy the metabolic needs of grapes (SFE/kg grapes). Exposed Leaf Area/production is an indicator that allows keeping under control the quality of grape production. The optimal value of this index is specific to the variety and viticultural terroir. Under the ecopedoclimatic conditions of the area DOC Dealu MareValea Calugareasca the maximum sugars potential of carbohydrate metabolism, determined by the correlation analysis, was achieved as the SFE/P $1.85 \mathrm{sqm} / \mathrm{kg}$ at 'Riesling italian', $1.41 \mathrm{sqm} / \mathrm{kg}$ at 'Feteasca regala', $1.85 \mathrm{sqm} / \mathrm{kg}$ at 'Merlot', $1.78 \mathrm{sqm} / \mathrm{kg}$ at 'Cabernet Sauvignon' and $1.83 \mathrm{sqm} / \mathrm{kg}$ at 'Burgund mare'. SFE/P correlation is specific to each viticultural terroir. The alcoholic potential of wine colour intensity was strength correlated with the SFE/P report. The optimal values of the SFE/kg report, identified at the varieties studied, underlying the differentiated technologies for viticulture in the area DOC Dealu Mare Valea Calugareasca.
\end{abstract}

Keywords: exposed leaf area, grape, viticultural terroir.

\section{INTRODUCTION}

The notion of "viticultural terroir" is a concept that was born in relation to the names of European origin. It represents a geographic defined area, in which a human community built throughout history a collective science of production, based on a system with interactions between the physical and biological environment and a set of human factors" (www.oiv2007.hu/documents/ viticulture/327_definition_du_terroir_oiv_ budapest.pdf).

At present it is recognized that the exposed leaf area is a quality parameter better than planting density to be used as a quality factor in the AOC regulations (www.vignevin-sudouest. com). The ratio SFE/kg grape (Exposed Leaf Area/ Production) is an indicator that allows keeping under control the quality of grape production. Carbonneau (1980, 1995), Murisier $(1996,1997)$ has established that it is necessary an exposed leaf area of 1.0-1.2 sqm to achieve $1 \mathrm{~kg}$ of grapes. Kliewer and Weaver (1971) adjusted crop levels in Tokay by pruning and cluster thinning and found that 1 to $1.4 \mathrm{~m} 2$ of leaf area was required to attain maximum berry mass, maturity and color.

Kliewer and Dokoozlian (2001), Renaud and Oustric (2001) analyzed data acquired from several studies in which combinations of leaf area density, 
crop load, canopy length and canopy number per vine were manipulated. Without canopy division, the leaf area required to ripen the fruit of several V. vinifera grape varieties ranged between 0.8 and $1.4 \mathrm{sqm}$ per $\mathrm{kg}$ of fruit. With division of the canopy to increase the leaf surface area exposed to sunlight, only 0.5 to $0.8 \mathrm{sqm}$ of leaf area per $\mathrm{kg}$ of fruit was required to ripen the crop. The ratio of crop mass to pruning mass, a commonly used vine balance index, was found to be closely related (negatively) to the ratio of leaf area to crop mass. Studies have shown that in Midi-Pyrenees (Dufourcq and Serrano, 2002) the potential of analyzed red varieties has improved when the value of this ratio has increased up to $2 \mathrm{sqm} / \mathrm{kg}$. The optimal value of this index is specific the variety and viticultural terroir. Knowing the value of this index is important because it allows developing differentiated technologies at viticultural parcel. In practice, the best way to obtain best value for this indicator is to correct the grape production. The present study was conducted to determine at the main varieties cultivated in the area DOC Dealu Mare-Valea Calugareasca the ratio values SFE/kg grapes to achieve the optimum quality of the grape harvest.

\section{MATERIALS AND METHODS}

The research was conducted during 20022005, in 10 viticultural terroir of the area Dealu Mare-Valea Calugareasca. Each viticultural terroir was described in the identification sheets special, designed for this research. The annual wine climate was assessed based on the parameters and indicators of bioclimatic vineyard.

In the vineyard, at the beginning of veraison was determined the exposed leaf area of vines. The determination was made on the 50 vines placed on diagonals of the plantation. The grapes were harvested at full maturity and grape harvest was quantitatively evaluated (kg/vine) and qualitatively by determining the sugars $(\mathrm{g} / \mathrm{l})$ of must.

The yield of control vines was vinified in microvinification conditions at the IC-DVV Valea Calugareasca through specific experimental wines production technology for assessing the oenological potential field. Next year, in March was done physico-chemical analysis of the composition of wines (the alcoholic potential and colour intensity). Data processing was done by statistics descriptive analysis and correlation analysis using the XLSTAT 2014 software.

\section{RESULTS AND DISCUSSION}

01. The description of the viticultural terroir

The viticultural terroir studied were located within a distance of 15 kilometers in the area DOC Dealu Mare-Valea Calugareasca (Fig. 1). The soil type at terroir level and their assortment are presented in table 1.

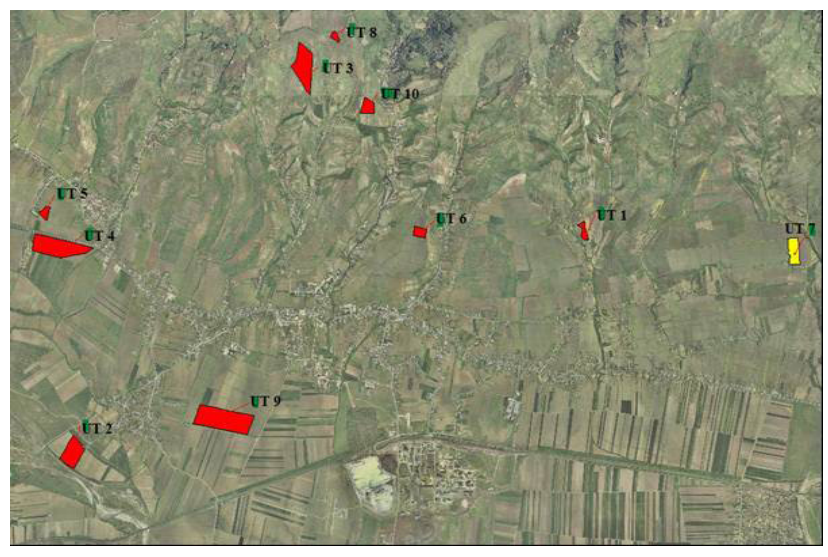

Fig. 1. The location of viticultural terroir.

Tab. 1. The data identification of viticultural terroir studied in the DOC Dealu Mare-Valea Calugareasca area.

\begin{tabular}{|c|c|c|}
\hline $\begin{array}{c}\text { The code of } \\
\text { the viticultural } \\
\text { terroir }\end{array}$ & The assortment & The type of the soil \\
\hline $\begin{array}{l}\text { Terroir unit } 1 \\
\text { (UT1) }\end{array}$ & 'Riesling italian’ & $\begin{array}{c}\text { Hortic, red, } \\
\text { argic, epicalcaric } \\
\text { anthrosol }\end{array}$ \\
\hline $\begin{array}{c}\text { Terroir unit } 2 \\
\text { (UT2) }\end{array}$ & 'Feteasca regala' & Dystric alluviosol \\
\hline $\begin{array}{c}\text { Terroir unit } 3 \\
\text { (UT3) }\end{array}$ & 'Feteasca regala' & $\begin{array}{l}\text { Hortic, entic } \\
\text { anthrosols }\end{array}$ \\
\hline $\begin{array}{c}\text { Terroir unit } 4 \\
\text { (UT4) }\end{array}$ & 'Merlot' & $\begin{array}{l}\text { Mollic, vertic } \\
\text { eutricambosol }\end{array}$ \\
\hline $\begin{array}{c}\text { Terroir unit } 5 \\
\text { (UT5) }\end{array}$ & 'Merlot' & Vertic preluvosol \\
\hline $\begin{array}{l}\text { Terroir unit } 6 \\
\text { (UT6) }\end{array}$ & $\begin{array}{l}\text { 'Cabernet } \\
\text { Sauvignon' }\end{array}$ & $\begin{array}{c}\text { Reddish, mollic, } \\
\text { vertic, stagnic } \\
\text { preluvosol }\end{array}$ \\
\hline $\begin{array}{c}\text { Terroir unit } 7 \\
\text { (UT7) }\end{array}$ & $\begin{array}{l}\text { 'Cabernet } \\
\text { Sauvignon' }\end{array}$ & $\begin{array}{l}\text { Hortic, entic, red } \\
\text { anthrosol }\end{array}$ \\
\hline $\begin{array}{c}\text { Terroir unit } 8 \\
\text { (UT8) }\end{array}$ & 'Burgund mare' & $\begin{array}{l}\text { Brownish slightly } \\
\text { eroded vertosol }\end{array}$ \\
\hline $\begin{array}{l}\text { Terroir unit } 9 \\
\text { (UT9) }\end{array}$ & 'Burgund mare' & Colluvic alluviosol \\
\hline $\begin{array}{l}\text { Terroir unit } 10 \\
\text { (UT10) }\end{array}$ & 'Burgund mare' & $\begin{array}{l}\text { Hortic, argic, vertic, } \\
\text { stagnic anthrosol }\end{array}$ \\
\hline
\end{tabular}


Soil types present a very large variation in terms of texture, mostly of the soil having a heavy texture (clay loam and loam-clay). Clay $(<$ $0,002 \mathrm{~mm}$ ) was found between $48.6 \%-56.9 \%$ reddish preluvosols; between $25.8-56.5 \%$ at colluvic alluviosol; between $16.5-60.7 \%$ at hortic antrosols; between $46.3-51.3 \%$ at eutricambisol and between $47.2-61.3 \%$ at vertosols. Soils with more than $50 \%$ clay $(<0,002 \mathrm{~mm})$ due to the high compactness, lack of aeration, the phenomena of inflation and contracting due to its predominantly clay minerals montmorillonitics, determine a limitation of the development of the root system, its destruction, sometimes involving a poor fructification of wine. Also in argiloiluviale soils due to the accumulation of clay in an additional Bt horizon under conditions of excess rainfall, sometimes create a zone with stagnant water with asphyxiant effect on the roots. Sandy soil provides good permeability, reduce the influence of excessive moisture particularly harmful during the maturation of the grapes. On these soils, vine has a root system penetrates to the depths ensuring the plant with water and nutrients. Clay soils are generally very compact, potentiates the quality of grapes, with good permeability and a positive influence on excess moisture, thereby improving the thermal regime of the ground. The very different pedological and agrochemical characteristics of soils had a major impact on the behaviour of the vinifera species. This impact was amplified by ecoclimatic specific conditions of Valea Calugareasca vineyard by a low level of rainfall in July and August, which determined to a hydric stress, which was manifested with greater intensity on the sandy soils (alluviosols). Reddish, mollic, vertic, stagnic preluvosol soil (UT
6) ensures the uniform development of the root system, followed by preluvosols vertic, at which an increase in the number of roots from the lower half of the horizon sloppy (UT 7). In the case of molic eutricambosols (UT 4) most of the roots are found in the second third of the sloppy horizon Bv (rich in clay) here being found a drastic decrease in the number of roots (only $5.7 \%$ of all roots).

Vertisols (UT-5) shows immediately the surface after a minimum number of roots then will develop sloppy in the horizon, where the horizons $\mathrm{A}$ and By shows a modified structure, cracks and possibilities of higher strike. In sloppy horizons, the number of roots decreases almost to extinction, the depth of $60-100 \mathrm{~cm}$ growth only about $21 \%$ of all roots, their presence on $90-100 \mathrm{~cm}$ depth being only $1.9 \%$. Aluviosols (UT-2 and-9) presents the largest number of roots in the horizons where clay content is higher, in the horizons Ao $(67 \%$ of all roots) and AC ( $26 \%$ of all roots). With decreasing clay content in the soil depth, number of roots is reduced drastically $(0.3-3.3 \%)$ due to very low water and nutrients resources and nutrition (basically these horizons are composed of sand mixed with gravel). In the case of hortic antrosols (UT 1, 3, 7, and 10) number of roots decreases from the surface to the depth, depending on the clay content, the content of calcium carbonate and the intensity of mixed natural horizons through terracing.

\section{Viticultural climate of the study period}

In the studied period the annual vineyard climate showed a small variation, 2005 being a unfavourable viticultural year (2005) and the years 2002, 2003 and 2004 being very good years.

Recorded data indicate a thermal regime characterized by an annual average temperatures

Tab. 2. Quality viticultural climate in the period 2002-2005.

\begin{tabular}{|c|c|c|c|c|}
\hline Climatic indicator/year & 2002 & 2003 & 2004 & 2005 \\
\hline The absolute minimum temperature $\left({ }^{\circ} \mathrm{C}\right)$ & -16.2 & -14.0 & -15.0 & -16.4 \\
\hline The average annual temperature $\left({ }^{\circ} \mathrm{C}\right)$ & 14.0 & 12.6 & 12.8 & 11.8 \\
\hline Active heat balance $\left(\Sigma \mathrm{t}^{\circ} \mathrm{C}\right)$ & 3579 & 3677 & 3444 & 3448 \\
\hline Useful heat balance $\left(\Sigma \mathrm{t}^{\circ}{ }^{\circ} \mathrm{C}\right)$ & 1869 & 1946 & 1674 & 1687 \\
\hline Global heat balance $\left(\Sigma \mathrm{t}^{\circ}{ }^{\circ} \mathrm{C}\right)$ & 3653 & 3744 & 3491 & 3492 \\
\hline The amount of hours of insolation during the growing $\left(\Sigma \mathrm{i}_{r}\right)$ & 1256 & 1465 & 1262 & 1358 \\
\hline Annual precipitation amount (mm) & 630 & 650 & 636 & 1079 \\
\hline The rainfall amount during the growing ( $\mathrm{mm})$ & 401 & 362 & 370 & 825 \\
\hline Huglin heliothermal index $(\mathrm{IH})$ & 1903 & 1956 & 1831 & 1832 \\
\hline Index cooler nights (IF) & 12.7 & 12.3 & 12.9 & 13.8 \\
\hline Degree days Winkler & 1618 & 1720 & 1533 & 1544 \\
\hline
\end{tabular}


that oscillate between $11.8^{\circ} \mathrm{C}(2005)$ and $14.0^{\circ} \mathrm{C}$ (2002) (Tab. 2), a global heat balance that varied between $3491^{\circ} \mathrm{C}(2004)$ and $3744^{\circ} \mathrm{C}(2003)$, a sum of active temperatures between $3444^{\circ} \mathrm{C}$ (2004) and $3677^{\circ} \mathrm{C}$ (2003) and an amount of useful temperatures between $1674^{\circ} \mathrm{C}$ (2004) and $1946^{\circ} \mathrm{C}$ (2003). Index cooler nights was framed in the classes of climate with cool nights (IF3: 1214) with values between $12.3^{\circ} \mathrm{C}(2003)$ and $13.8^{\circ} \mathrm{C}$ (2005).

Rainfall during the growing season of the vine amounted to an average of $362 \mathrm{~mm}$ in 2003 and $825 \mathrm{~mm}$ in 2005.

3. The variability of the SFE/P ratio according to the variety

In conditions in which the cutting was done of the same fruit loads, the annual climate and the variety influenced significantly the SFE/P ratio of the vines. The variability of this parameter was lower at the varieties 'Merlot' and Cabernet Sauvignon, medium at 'Riesling italian' and very high at 'Feteasca regala' and 'Burgund mare' (Fig. 2).

The average value of the SFE/P report was specific to the variety as follows: 1.62 for 'Feteasca regala', 1.82 for 'Riesling italian', 1.77 for 'Merlot', 1.69 for 'Cabernet Sauvignon' and 1.61 for 'Burgund mare'. This ratio has varied between 1.25 and 1.85 at 'Feteasca regala', between 1.69 and 1.98 at 'Riesling italian', 1.67 and 1.92 at 'Merlot', 1.54 and 1.89 at 'Cabernet Sauvignon' and between 1.17 and 1.92 at 'Burgund mare' (Fig. 3).

4. Correlation of SFE/P rapport with the quality of the grape harvest
The sugars potential of the harvest of 'Riesling italian' variety presented values between 196 and $203 \mathrm{~g} / \mathrm{l}$ sugars. The relationship between the concentration of sugars and the SFE/P report (Fig. 4) had the following form:

\section{$Y=-370 x^{2}+1369 x-1061$ (1)}

Maximum of sugars (206 g/l), calculated on the basis of the relationship 1, is recorded when $\mathrm{SFE} / \mathrm{P}$ report has a value of $1.85 \mathrm{sqm} / \mathrm{kg}$.

For the same variety, the viticultural terroir can influence the relationship between sugars and $\mathrm{SFE} / \mathrm{P}$ ratio.

Thus, at 'Feteasca regala' variety cultivated in the terroir unit 2 the maximum sugars concentration $(208 \mathrm{~g} / \mathrm{l})$ was achieved at a value of $1.80 \mathrm{SFE} / \mathrm{P}$ ratio. In terms of ecopedoclimatic conditions of the terroir unit 3 the maximum sugars content was $218 \mathrm{~g} / \mathrm{l}$ at a value of $1.41 \mathrm{sqm} /$ vine (Fig. 5).

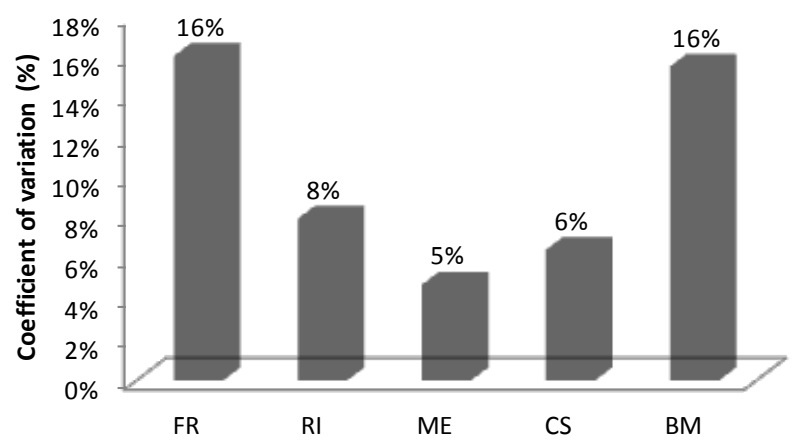

Note: FR = Feteasca regala, RI = Riesling italian, $\mathrm{ME}=$ Merlot, $\mathrm{CS}=$ Cabernet Sauvignon, BM = Burgund mare.

Fig. 2. The variability of the SFE/P ratio at the grapes varieties cultivated in Valea Calugareasca vineyard.

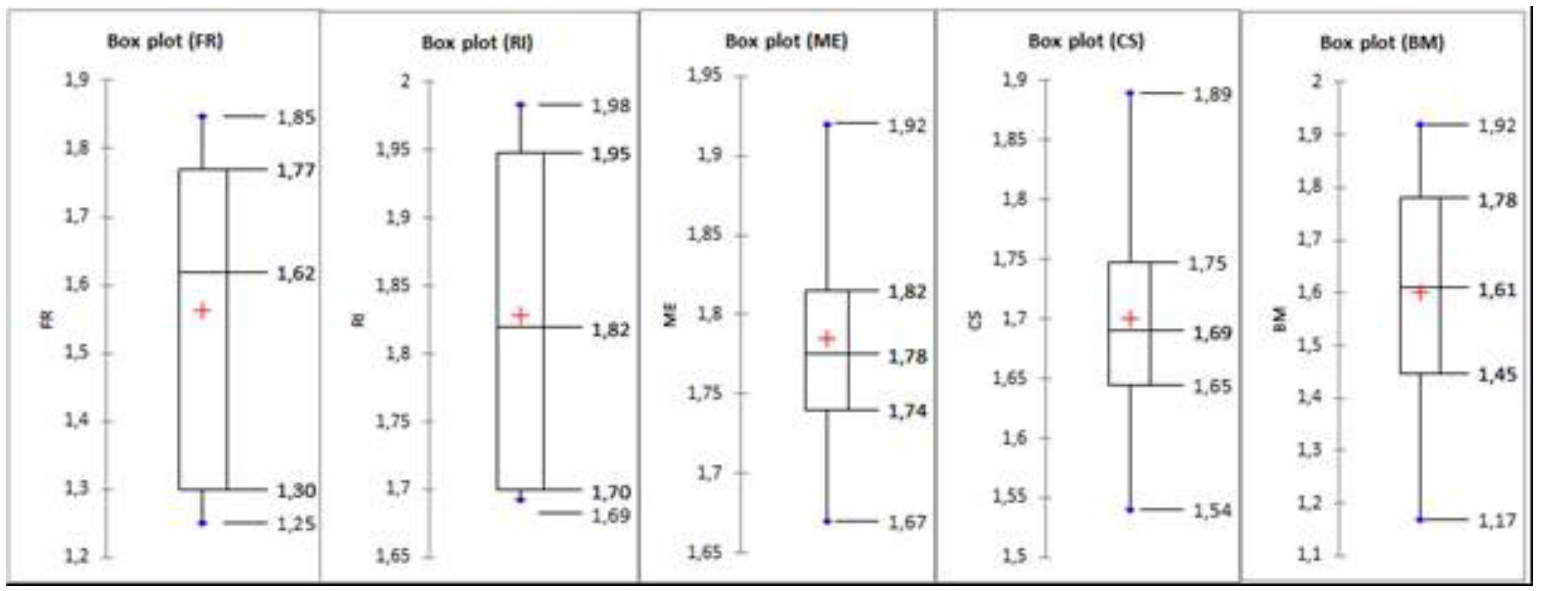

Note: $\mathrm{FR}=$ Feteasca regala, $\mathrm{RI}=$ Riesling italian, $\mathrm{ME}=$ Merlot, $\mathrm{CS}=$ Cabernet Sauvignon, $\mathrm{BM}=$ Burgund mare.

Fig. 3. Statistical parameters of variation of the SFE/P in Valea Calugareasca vineyard. 
In case of 'Merlot' variety, for accumulating the maximum quantities of sugars in grapes $(216$ $\mathrm{g} / \mathrm{l})$ in the terroir unit3, the optimal value of SFE/P ratio is $1.85 \mathrm{sqm} /$ vine, and in the terroir unit 4 reaching the maximum of sugars content $(212 \mathrm{~g} / \mathrm{l})$ is achieved at a SFE/P report of $1.73 \mathrm{~m}^{2} /$ vine (Fig. 6).

The correlation between the SFE/P ratio and the concentration of sugars in the case of the 'Cabernet Sauvignon'variety in the two terroir units is represented by polynomial functions, distinctively significant $\left(\mathrm{Y}=-1071 \mathrm{x}^{2}+3520.1\right.$ $2679, \mathrm{R}^{2}=0.9907^{* *}$ in the terroir unit 6 and $\mathrm{Y}$ $=-511 \mathrm{x}^{2}+1822 \mathrm{x}-1410, \mathrm{R}^{2}=0.9867^{* *}$ terroir unit 7). For terroir unit 6, maximum accumulation of sugars $(214 \mathrm{~g} / \mathrm{l})$ is achieved at a SFE/P report

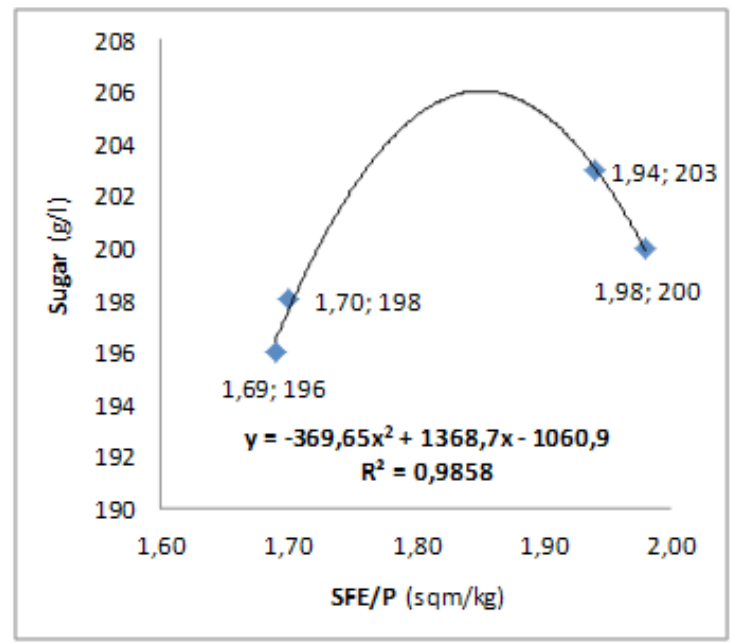

Fig. 4. The relationship between the sugar concentration and the SFt/P ratio at 'Riesling italian' variety.
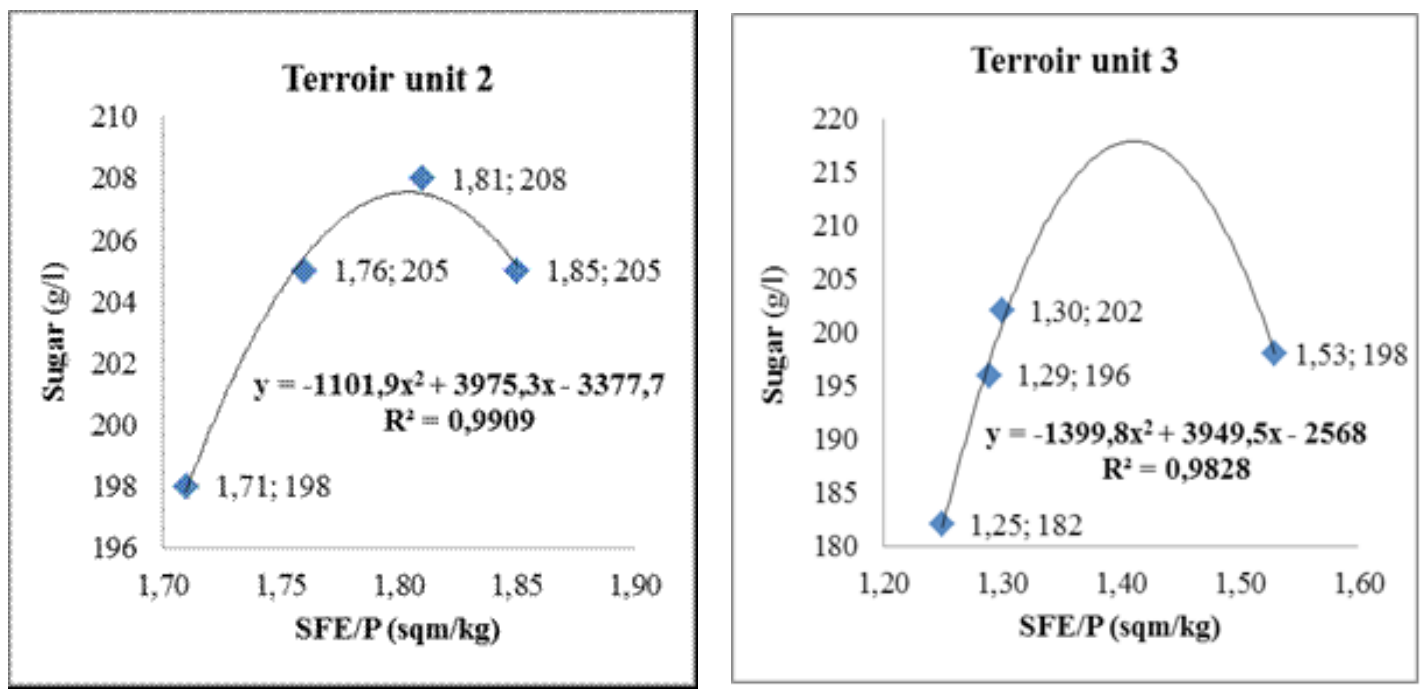

Fig. 5. The relationship between the sugar concentration and the SFt/P report at 'Feteasca regala' variety.
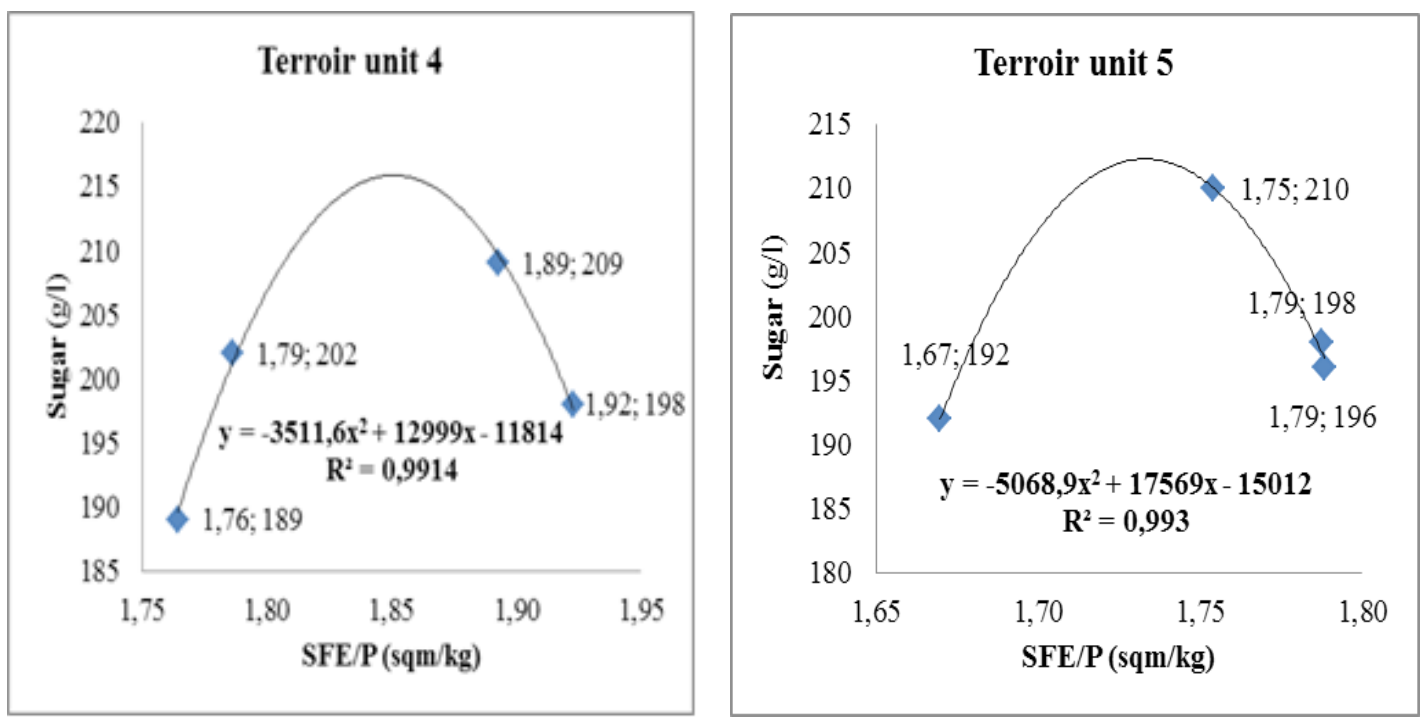

Fig.6. The relationship between the sugar concentration and the SFE/P ratio at 'Merlot' variety. 

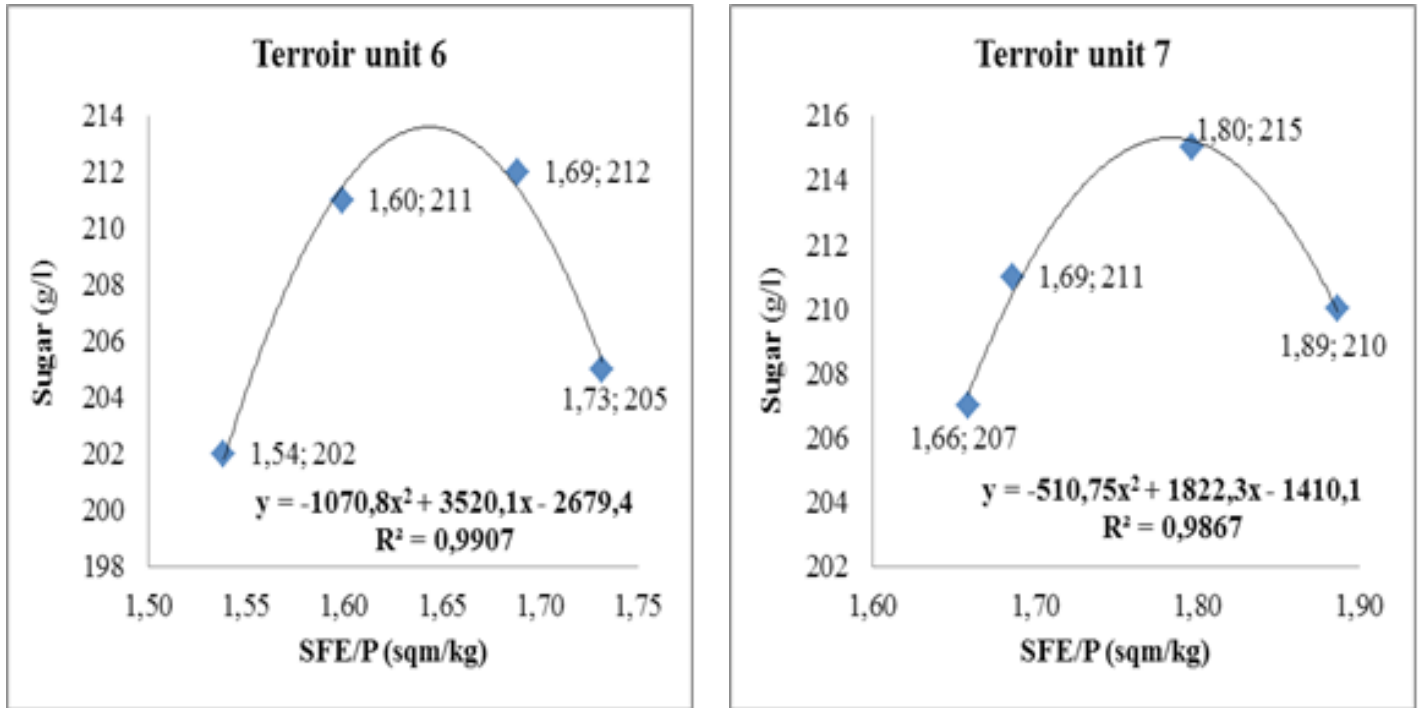

Fig. 7. The relationship between the sugar concentration and the SFt/P report at 'Cabernet Sauvignon' variety.

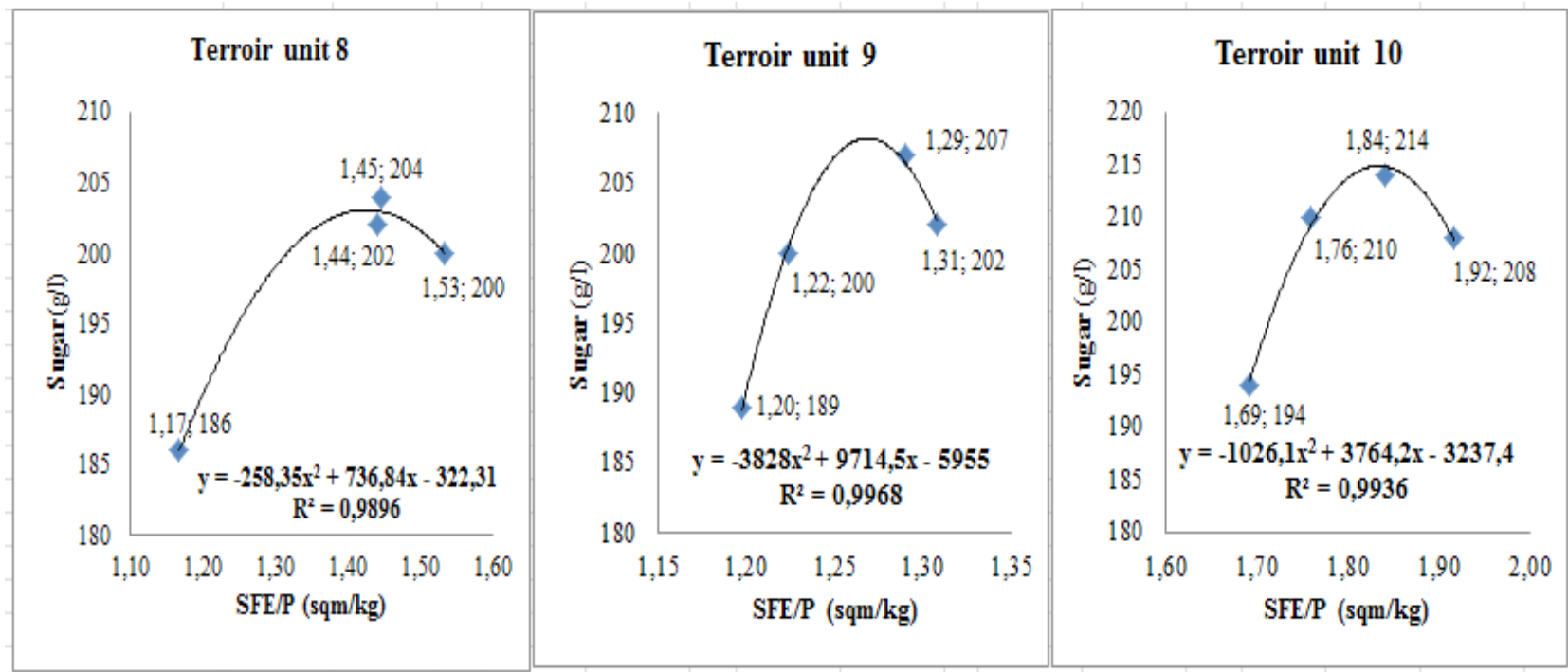

Fig. 8. The relationship between the sugar concentration and the SFt/P ratio at 'Burgund mare' variety.

of $1.64 \mathrm{sqm} / \mathrm{vine}$, and for the terroir unit 7 of maximum sugars $215 \mathrm{~g} / \mathrm{l}$ shall be carried out at a SFE/P ratio of 1.78 sqm/vine (Fig. 7).

For the 'Burgund mare' variety between SFE/P report values and concentration in sugars there are a distinct correlations in case of three terroir units $\left(\mathrm{R}^{2}=0.9896^{* *}\right.$ for the terroir unit $8, \mathrm{R}^{2}=0.9968^{* *}$ for the terroir unit 9 and $\mathrm{R}^{2}=0.9936^{* *}$ for the terroir unit 10). SFE/P ratio values ranging from $1.27 \mathrm{sqm} / v i n e$ (the terroir unit 9) $1.43 \mathrm{sqm} /$ vine (the terroir unit 8) and $1.83 \mathrm{sqm} /$ vine (the terroir unit 10), determine the maximum concentration of sugars content of $208 \mathrm{~g} / \mathrm{l}$ (Terroir unit 9), 203 g/l (Terroir unit 8) and $215 \mathrm{~g} / \mathrm{l}$ (Terroir unit 10) (Fig. 8).
5. Correlation of SFE/P ratio with the quality of wines

The alcoholic potential is strongly correlated with the SFE/P report. The growth rate of the alcoholic potential when the SFE/P ratio increases with 0.10 units is specific for each variety and terroir units. The highest values were recorded at 'Feteasca regala' $(0.79 \%$ vol. alcohol/0.10SFE/P) and 'Cabernet Sauvignon' (0.75\% vol. alcohol/0.10 $\mathrm{SFE} / \mathrm{P}$ ) and the lowest at the 'Burgund mare' ( $0.27 \%$ vol. alcohol/0.10 SFE/P) (Fig. 9).

The intensity of wine colour increased when the SFE/P report has increased. The improving of colour intensity was very high at 'Cabernet Sauvignon' wines $(0.70$ at the UT6 and 0.76 at the 


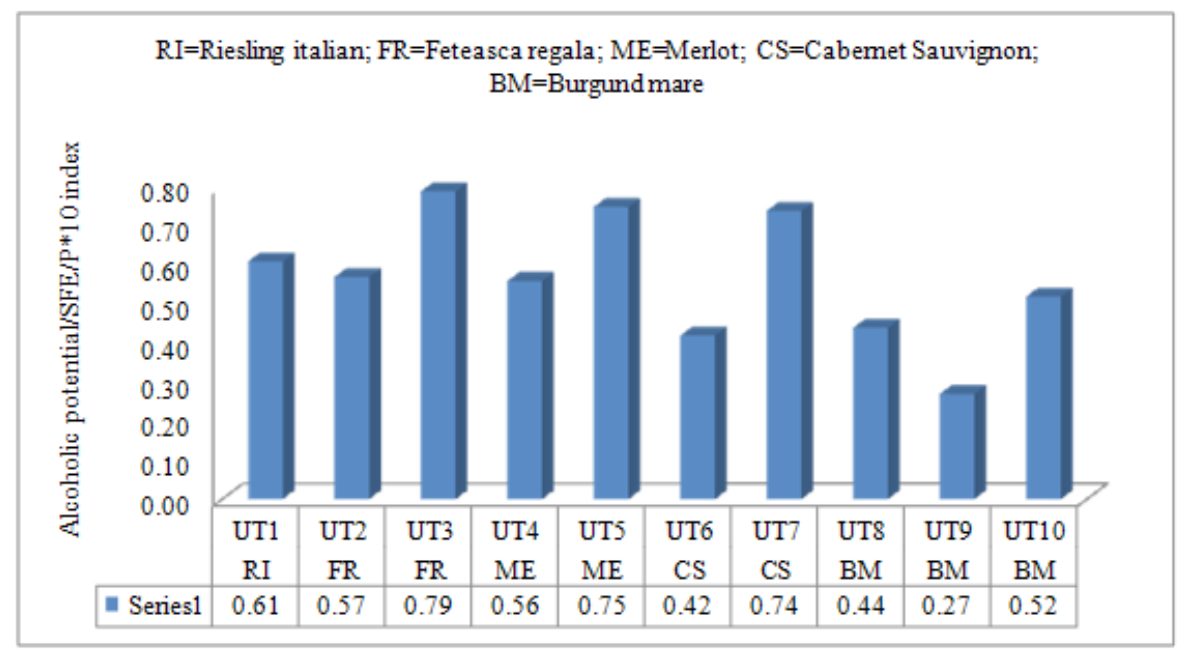

Fig. 9. Growth rate of alcoholic wine potential depending on the SFE/P ratio at the main varieties in the DOC Dealu Mare-Valea Calugareasca area.

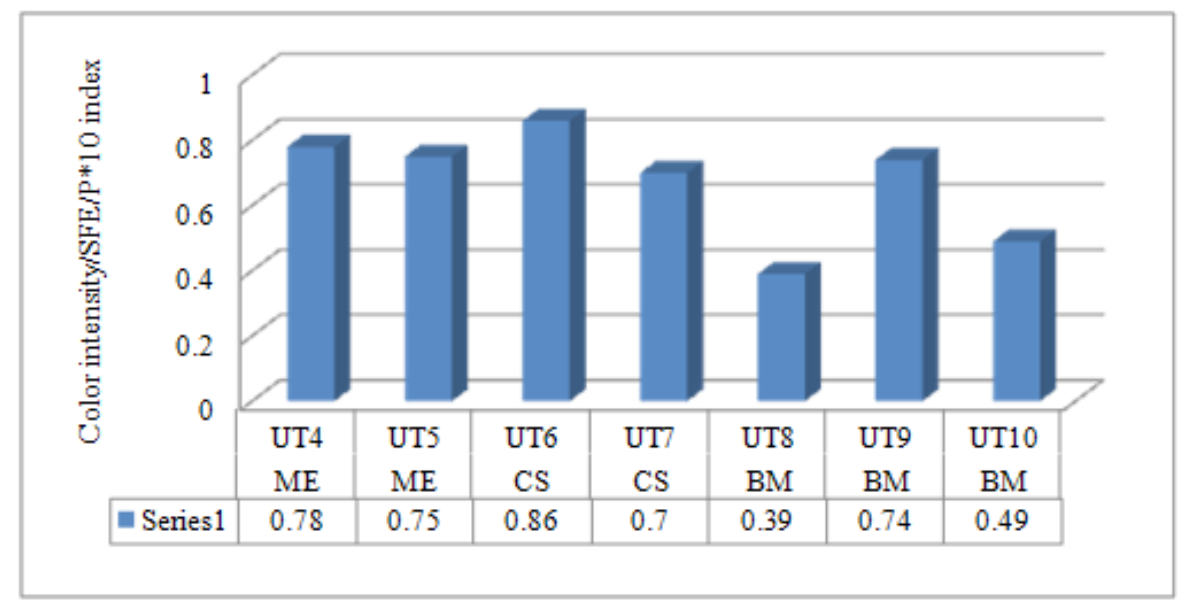

Note: $\mathrm{FR}=$ Feteasca regala, RI = Riesling italian, ME = Merlot, $\mathrm{CS}=$ Cabernet Sauvignon, $\mathrm{BM}=$ Burgund mare.

Fig. 10. The colour intensity of wines depending on the SFE/P ratio.

UT7) and 'Merlot' (0.75 at UT4 and 0.78 at UT5) (Fig. 10). At the 'Burgund mare' variety, cultivated in the terroir unit 9 , the growth rate of the colour intensity was similar to that of the 'Merlot' and 'Cabernet Sauvignon' varieties. Terroir units 8 and 10 have potentiated the colour intensity of wines with the lowest rate of growth.

\section{CONCLUSION}

$\mathrm{SFE} / \mathrm{P}$ ratio can be an indicator for the evaluation of wine quality of terroir units.

The viticultural terroir units studied are representative of the area and the assortment of DOC Dealu Mare Valea Calugareasca. The soil types present a very large variation in terms of texture, mostly of the soil heaving a heavy texture (clay loam and loam-clay). Clay $(<0,002 \mathrm{~mm})$ was found between $48.6 \%-56.9 \%$ at reddish preluvosols; between $25.8-56.5 \%$ at colluvic alluviosol; between $16.5-60.7 \%$ at hortic antrosols; between $46.3-51.3 \%$ the eutricambisol and between 47.2$61.3 \%$ at vertosols.

Due to their position on the slopes, most of the soils allow a deep root system development and moderate the climate excesses by limiting the effects of the long-lasting drought or by eliminating the water surplus, resulting therefore in a constant water supply for the grapevine. The diagram of the root system distribution in case of the vinifera/rootstock combinations is differentiated according to the soil type, clay content, nature of clay mineralogy and to the full and active calcium carbonate content. 
The delimited soil types, morphologically and agrochemically representing different entities show a differentiated suitability in terms of obtaining optimal productions in respect of their quantity and quality, depending on their mineralogical, physical and agrochemical characteristics.

The study was conducted during a period of years which included 3 years with very good climatic conditions and an unfavourable year.

In the period 2002-2005, SFE/P ratio variation was small at 'Cabernet Sauvignon' and 'Merlot', medium at 'Riesling italian' and very high at 'Feteasca regala' and 'Burgund mare'.

The maximum potential of sugars accumulation, established by the correlation analysis, was achieved at the SFE/P report of $1.85 \mathrm{sqm} / \mathrm{kg}$ at 'Riesling italian', $1.41 \mathrm{sqm} / \mathrm{kg}$ at 'Feteasca regala', $1.85 \mathrm{sqm} / \mathrm{kg}$ at 'Merlot', 1.78 $\mathrm{sqm} / \mathrm{kg}$ at 'Cabernet Sauvignon' and $1.83 \mathrm{sqm} / \mathrm{kg}$ at 'Burgund mare'. SFE/P correlation is specific to each viticultural terroir unit.

The alcoholic potential of wines is strongly correlated with the SFE/P ratio. Growth rate of alcoholic potential of wines at an increase of 0.10 units of SFE/P ratio varied between $0.27 \%$ vol alcohol ('Burgund mare') and $0.79 \%$ vol. alcohol ('Feteasca regala').

Colour intensity of wines has improved with increasing of SFE/P ratio, the growth rate being specific to the variety and viticultural terroir.

\section{REFERENCES}

1. Dufourcq T, Serrano E (2002). Determination du rapport feuilles/fruits optimal pour quatre principaux cepages de la regions Midi-Pyrenees. Actes du colloque $<<$ Gestion du rendement vers une recherche de la qualite>>. Station regionale ITV Midi-Pyrenees: 36-42.

2. Carbonneau A., (1980). Recherche sur les systèmes de conduite de la vigne : essai de maîtrise du microclimat et de la plante entière pour produire économiquement du raisin de qualité. Thèse de Docteur Ingénieur. Université de Bordeaux II

3. Carbonneau A., (1995). L'exposition du feuillage : définition du potentiel du système de conduite. Système de conduite de la vigne et mécanisation., OIV Ed., Paris, 13-33 et C.R. GESCO, 4, 25-44.

4. Kliewer WM, Weaver RJ (1971). Effect of crop level and leaf area on growth, composition and coloration of 'Tokay' grapes. Am. J. Enol. Vitic. 22:172-177.

5. Kliewer WM, Dokoozlian NK (2001). Leafarea/crop weight ratios of grapevines: Influence on fruit composition and wine quality. Proceedings of the ASEV 50th Anniversary Annual Meeting. J.M. Rantz (Ed.), pp. 285-289.

6. Murisier F (1996). Optimisation du rapport feuille-fruit de la vine pour favoriser la qualite du raisin et l' acumulation des glucides de reserve. These de doctorat. EPF Zurich,p. 132 .

7. Murisier F, Zufferey V (1997). Rapport feuille-fruit de la vigne et qualite du raisin. Revue suisse Vitic. Hortic. 28:355-362.

8. Renaud C, Oustric J (2001). Optimisation de la conduite de vitis vinifera cv Mourvèdre par la variation du rapport feuillage exposé-fruits. Compte rendu des XIIèmes journées du GESCO Montpellier. AGRO Montpellier, 682p.

9. www.vignevin-sudouest.com/publication/itv. Influence du rapport feuile/fruit sur la qualite des mouts et des vins.

10. www.oiv2007.hu/documents/viticulture. Definition du terroir. 